\title{
Regulatory peptides
}

The Editors wish to thank Professor J. M. Polak for coordinating this review.

\section{Introduction}

\author{
by J.M. Polak and S. R. Bloom
}

Department of Histochemistry and Medicine, Royal Postgraduate Medical School, Hammersmith Hospital, Du Cane Road, London W12 OHS (England)

Key words. Autonomic/sensory nerves; chromatography; endocrine cells; enzymes; immunocytochemistry; neuropeptides; neurotransmitters; processing of peptides; radioimmunoassay; regulatory peptides; quantification.

For some time Experientia has been publishing, as a unique feature, interdisciplinary multi-author reviews that report comprehensively on topics regarded as 'growing edges' of science.

The participants of the present issue, all interested in aspects of 'regulatory peptides' are pleased to contribute articles on this subject.

The topic 'regulatory peptides' is relatively young and has grown at an unprecedented pace, from the embryonic conception of 'gut hormones' or 'brain neuropeptides' some 15 years ago to the realisation that these active peptides are found with almost no exception in every part of the body in all vertebrate ${ }^{11}$ and many invertebrate species ${ }^{14}$.

Why the term 'regulatory peptides'? It represents an attempt to include both the active peptides present in nerves, and released as (putative) neurotransmitters, and those in endocrine cells, acting locally or at a distance as circulating hormones, these two being the main components of the so-called diffuse neuroendocrine ${ }^{11}$ or APUD system ${ }^{10}$.

Knowledge of the extent of the regulatory peptide-containing system is by no means complete. Peptides are discovered at a high rate from the skin of amphibians ${ }^{3}$ (e.g. bombesin), or extracts of primitive invertebrates ${ }^{14}$ (e. g. Hydra head activating peptide) to the disclosure of a novel mammalian cDNA structure ${ }^{12}$ (calcitonin gene-related peptide), or new peptides identified by the characteristic amide at the C-terminus $^{13}$ (e. g. NPY, PYY, galanin).

The anatomical and physiological confines of regulatory peptides are becoming blurred, encroaching on all areas of the body and all disciplines. This is illustrated by the recently discovered $56 \mathrm{KD}$ neurotrophic peptide termed neuroleu$\mathrm{kin}^{6}$. This novel peptide which promotes neuronal growth has been extracted and cloned from mouse salivary gland and demonstrated also to be a lymphokine product of lectin stimulated T-cells, hence its name, neuroleukin. The amino acid sequence of neuroleukin is partly homologous to highly conserved regions of the external envelope protein of the Human T Leukaemia Virus III (HTLV III), the retrovirus responsible for AIDS.

Analysis of the genetic code for regulatory peptides has provided interesting information. It is now, for instance, well recognised that a single gene may encode more than one regulatory peptide (eg CGRP and calcitonin, VIP and PHI); likewise, more than one gene has recently been shown to code for the same or a closely similar peptide ( $\alpha$ and $\beta$ CGRP, the neurokinins etc.).

The processing of peptides from larger precursors has attracted considerable interest lately (see this issue) and although the precise enzymic machinery involving each step is still poorly understood, considerable information may be gained from the application of advanced procedures for chemical characterisation (chromatography, fast atom bombardment techniques) and the use of region-specific antibodies. An illustration is given by the tissue-specific processing of two separate but chemically related peptides VIP/PHI in different areas; for instance, in the stomach, nasal mucosa and genital tract, PHI, derived from the same precursor as VIP, is not processed to the original 27 amino acid peptide but rather into a larger, 42 amino acid peptide termed $\mathrm{PHV}^{16}$ (fig. 1).

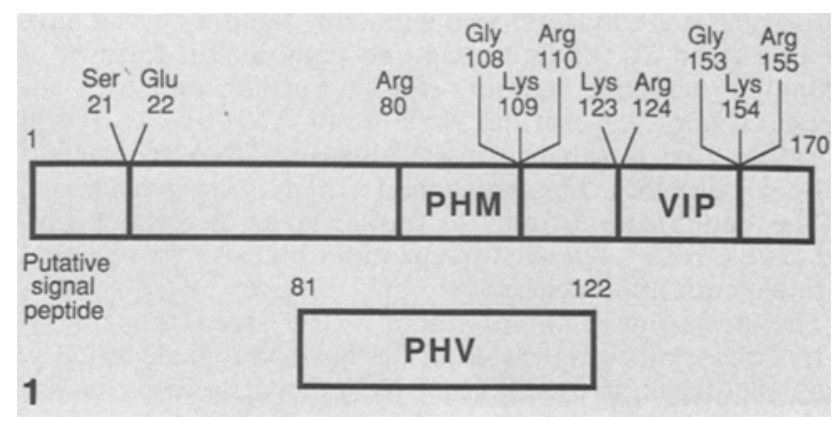

Figure l. Diagram showing the structure of pre-pro-VIP and the positions of three derivative peptides: peptide histidine methionine (PHM human equivalent of PHI), vasoactive intestinal peptide (VIP) and pre-pro-VIP 91-122 (PHV-42).

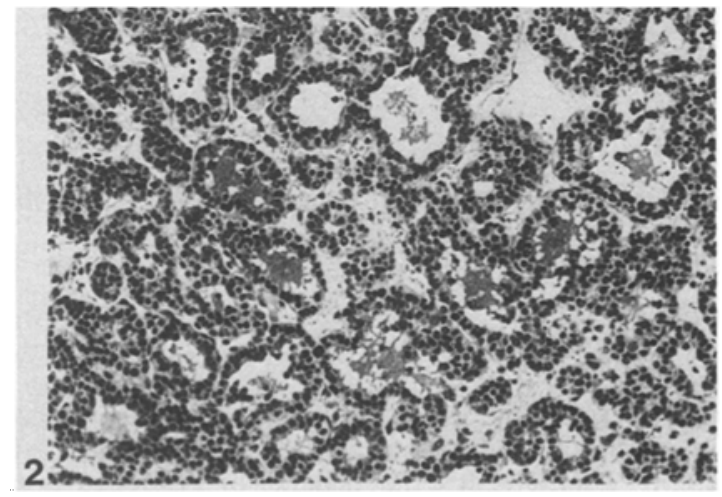

Figure 2. Pancreatic tumour from a transgenic mouse showing a predominantly acinar pattern. Haematoxylin and eosin stain. Bouin's fixed tissue $5 \mu \mathrm{m}$ wax section. $\times 250$. 
Regulatory peptide localisation has moved from the descriptive, static stage to an inspiring state of dynamic studies. The seminal work of Orci and colleagues has revealed an exciting 'functional morphology' of the $\beta$ cel1 ${ }^{8,9}$. By the use of modern electron microscopical immunocytochemistry using regionspecific antibodies recognising specific epitopes of proinsulin and insulin itself and by measuring intracellular $\mathrm{pH}$, Orci and colleagues have been able to monitor and compartmentalise the intracellular events that take place during insulin biosynthesis. This approach, together with the increasing use of in situ hybridisation (see this issue) for the localisation of peptide mRNA species and of peptide binding sites, by in vitro autoradiography (see this issue), will permit further disclosure of the morphological events involved in peptide synthesis, release and subsequent receptor activation.

Pharmacological manipulation of the regulatory system has permitted further understanding of the putative roles of its components. For instance the use of 8-methyl-N-vanillyl 6non-enamide (capsaicin), a compound found in extracts of red pepper and know to deplete and damage sensory neurons, has provided evidence supporting the sensory nature of peptides such as substance $\mathrm{P}$ and $\mathrm{CGRP}^{5}$. Furthermore the use of 6-hydroxydopamine and reserpine has demonstrated that the novel peptide NPY coexists with catecholamines in the sympathetic nervous system ${ }^{1}$. The search for specific peptide blockers is avid and although progress has been slow some advances have recently been made ${ }^{2,4}$ (substance $\mathbf{P}$ and bombesin analogues and antagonists, and CCK antagonists, have been added to the list of the originally discovered naloxone for blocking the actions of enkephalin).

Manipulation of the regulatory peptide system will certainly come from the increasing use of gene transfer technology. The construction of hybrid genes (SV40 plus a regulatory peptide promoter) has been used for some time. This has led to experimentally developed endocrine tumours which have reproduced all the biological and pathological features of human endocrine tumours (fig. 2). Further, and with advanced knowledge of the structure of RNA species, it will certainly be possible to insert antisense RNA sequences ${ }^{15}$ which will block the expression of a mRNA in a given tissue. This could lead not only to further areas of research into possible roles of regulatory peptides but also to potential therapeutic approaches.

The suggestion of a multi-author review issue is thus timely. It is clear that considerable strides have been made recently, by the development of novel technology, towards understanding the significance of the regulatory peptide system. This issue addresses some of the most fundamental questions.

1 Allen, J. M., Rodrigo, J., Yates, J. C., Savage, A.P., Polak, J. M., and Bloom, S. R., Vascular distribution of neuropeptide Y (NPY) and effect on blood pressure. Clin. exp. Hypertens. A6 (1984) 1879-1882.
2 Chang, R.S. L., and Lotti, V.J., Biochemical and pharmacological characterisation of an extremely potent and selective non-peptide cholecystokinin antagonist. Proc. natn. Acad. Sci. USA 83 (1986) 4923-4926.

3 Erspamer, V., and Melchiorri, P., Active polypeptides: from amphibian skin to gastrointestinal tract and brain of mammals. Trends Pharm. Sci. 1 (1980) 39l-394.

4 Evans, B.E., Bock, M.G., Rittle, K.E., Di Pardo, R.M., Whitter, W. L., Veber, D.F., Anderson, P.S., and Freidinger, R. M., Design of potent, orally effective, non-peptidal antagonist of the peptide hormone cholecystokinin. Proc. natn. Acad. Sci. USA 83 (1986) 4918-4922.

5 Gibson, S. J., Polak, J.M., Bloom, S. R., Sabate, I. M., Mulderry, P. M., Ghatei, M. A., McGregor G.P., Morrison, J. F. B., Kelly, J.S., Evans, R. M., and Rosenfeld, M. G., Calcitonin gene-related peptide immunoreactivity in the spinal cord of man and of eight other species. J. Neurosci. 4 (1984) 3101-3111.

6 Gurney, M.E., Heinrich, S.P., Lee, M. R., and Hsiang-Shu, Y., Molecular cloning and expression of neuroleukin, a neutrophic factor for spinal and sensory neurons. Science 234 (1986) 566-574.

7 Hanahan, D., Heritable formation of pancreatic $\beta$-cell tumours in transgenic mice expressing recombinant insulin/simian virus 40 oncogenes. Nature 315 (1985) 115-122.

8 Orci, L., Ravazzola, M., Amherdt, M., Madsen, O., Perrelet, A., Vassalli, J.-D., and Anderson, R. G. W., Conversion of proinsulin to insulin occurs coordinately with acidification of maturing secretory vesicles. J. Cell Biol. 103 (1986) 2273-2281

9 Orci, L., Ravazzola, M., Amherdt, M., Madsen, O., Vassalli, J.-D., and Perrelet A., Direct identification of the prohormone conversion site in insulin-secreting cells. Cell 42 (1985) 671-681.

10 Pearse, A.G. E., The cytochemistry and ultrastructure of polypeptide hormone-producing cells of the APUD series, and the embryologic, physiologic and pathologic implications of the concept. J. Histochem. Cytochem. 17 (1969) 303-313.

11. Polak, J.M., and Bloom, S. R., Immunocytochemistry of the diffuse neuroendocrine system, in: Immunocytochemistry: Modern Methods and Applications, 2nd edn, pp.328-348. Eds J.M. Polak and S. Van Noorden. John Wright \& Sons Ltd., Bristol 1986.

12 Rosenfeld, M.G., Mermod, J.J., Amara, S. G., Swanson, L.W., Sawchenko, P. E., Rivier, J., Vale, W. W., and Evans, R. M., Production of a novel neuropeptide encoded by the calcitonin gene via tissue-specific RNA processing. Nature 304 (1983) 129-135.

13 Tatemoto, K., Isolation of new peptides from brain and intestine, in: Frontiers of Hormone research, vol. 12, Interdisciplinary Neuroendocrinology, pp. 27-30. Eds M. Ratzenhofer, H. Höfler and G. F. Walter. Karger, Basel 1983

14 Van Noorden, S., The neuroendocrine system in protostomian and deuterostomian invertebrates and lower vertebrates, in: Evolution and Tumour Pathology of the Neuroendocrine System, pp. 7--38. Eds S. Falkmer, R. Hakanson and F. Sundler. Elsevier Science Publishers BV, Amsterdam 1984

15 Weintraub, H., Izant, J. G., and Hartland, R. M., Anti-sense RNA as a molecular tool for genetic analysis. Trends Genet. January (1985) $22-25$

16 Yiangou, Y., Di Marzo, V., Panico, M., Morris, H., and Bloom, S. R., Purification and sequence analysis of a novel 42 -amino acid peptide (PHV-42) that is contained in prepro-VIP. Regul. Pep. (Abst.) 15 (1986) 199.

$0014-4754 / 87 / 070723-02 \$ 1.50+0.20 / 0$

(C) Birkhäuser Verlag Basel, 1987

\title{
Regulatory peptide immunocytochemistry at light- and electron microscopical levels
}

\author{
by S. Van Noorden and I. A. Varndell*
}

Histochemistry Unit, Histopathology Department, Royal Postgraduate Medical School, Hammersmith Hospital, Du Cane Road, London W 12 OHS (England)

Summary. Immunocytochemical techniques applied at both light- and electron microscopical levels are valuable in the study of regulatory peptide distribution in normal and diseased tissue, whether in the form of sections or whole cell preparations. Successful immunolocalisation depends on 1) adequate preservation of the peptide antigen and the tissue structure in which it resides; 2) a suitably specific and sensitive labelled antibody detecting system. In general, peptides are stable molecules, most of which retain their antigenicity after conventional cross-linking fixation and tissue processing, allowing standard immunocytochemical methods to be used for light- and electron microscopy. Regulatory peptides are derived from precursor 